\title{
Passive sensitization of human airways increases responsiveness to leukotriene $\mathrm{C}_{4}$
}

\author{
D. Schmidt*, E. Ruehlmann*, D. Branscheid ${ }^{+}$, H. Magnussen ${ }^{+}$, K.F. Rabe*
}

\begin{abstract}
Passive sensitization of human airways increases responsiveness to leukotriene $C_{4} . D$. Schmidt, E. Ruehlmann, D. Branscheid, H. Magnussen, K.F. Rabe. (C)RS Journals Ltd 1999.

ABSTRACT: Passive sensitization of human airways in vitro causes increased responsiveness to histamine and induces specific immunoglobulin (Ig)E-dependent contractile responsiveness to allergen. Leukotrienes (LTs) and, to a lesser extent, histamine are the major mediators of allergen-induced contraction. Since it is unclear whether passively sensitized airways are also hyperresponsive to cysteinyl leukotrienes, this study investigated the effect of passive sensitization on $\mathrm{LTC}_{4}{ }^{-}$, in addition to histamine- and allergen-induced contractions in vitro.

Bronchial rings from nine nonatopic patients were sensitized overnight with serum containing high levels of total IgE $\left(>250 \mathrm{U} \cdot \mathrm{mL}^{-1}\right)$ and allergen-specific IgE against Dermatophagoides farinae (fluorescence allergosorbent test) (FAST class $\geq 3$ ).

The potency (- $\log _{10}$ of the mediator concentration causing a half maximal response (pEC50) of histamine was significantly increased in serum-sensitized tissues compared to nonsensitized controls $(($ mean \pm SEM) $p E C 505.20 \pm 0.27$ versus $5.64 \pm 0.18 ; p=0.02)$ and maximal contractions were enhanced $(877 \pm 47$ versus $543 \pm 51 \mathrm{mg} ; \mathrm{p}<0.0001)$. Similarly, the potency of $\mathrm{LTC}_{4}$ was significantly increased in sensitized compared to nonsensitized bronchial rings ( $\mathrm{pEC} 50$ 9.37 \pm 0.20 versus $8.66 \pm 0.26$; $\mathrm{p}=0.004)$; maximal contractions were also enhanced $(811 \pm 57$ versus $361 \pm 86 \mathrm{mg} ; \mathrm{p}<0.0001)$.

These data demonstrate that passive sensitization of human airways induces an increase not only in histamine but also in leukotriene responsiveness. Therefore, it might be speculated that allergen responses in sensitized airways are effected through a combination of increased mediator release from inflammatory cells and increased responsiveness of airway smooth muscle.

Eur Respir J 1999; 14: 315-319.
\end{abstract}

* Leiden University Medical Center, Dept of Pulmonology, Leiden, the Netherlands. +Krankenhaus Grosshansdorf, Zentrum für Pneumologie und Thoraxchirurgie, LVA Hamburg, Grosshansdorf, Germany.

Correspondence: K.F. Rabe

Leiden University Medical Center

Dept of Pulmonology

3C-P, P.O. Box 9600

NL-2333 ZA Leiden

The Netherlands

Fax: 31715266927

Keywords: Allergen bronchial responsiveness histamine human airways leukotrienes passive sensitization

Received: January 191999

Accepted after revision June 29199

Supported by a grant from GlaxoWellcome Medicines Research, UK.

Allergen-induced bronchoconstriction is one characteristic feature of bronchial asthma. Early and late phase responses to allergen in patients with asthma can almost be abolished by combined pretreatment with leukotriene (LT) and histamine receptor antagonists [1]. In close analogy to these in vivo findings, allergen-induced contractions of isolated airways obtained from patients with extrinsic asthma were also abolished after pretreatment with a combination of LT and histamine receptor antagonists in vitro [2]. Therefore, LTs and histamine are considered to be the most important mediators of allergen responses in human airways under in vivo as well as in vitro conditions.

Isolated airways from asthmatic patients are difficult to obtain. Therefore, passively sensitized isolated human airways serve as an in vitro model for airway hyperresponsiveness to explore the pathophysiological mechanisms which underly the induction of smooth muscle hypercontractility [3]. Passive sensitization, the incubation of tissue from normal individuals with immunoglobulin (Ig)E-rich serum, induces specific IgE-dependent responsiveness to allergen [4] and increases nonspecific responsiveness to histamine $[5,6]$. Furthermore, it has been demonstrated that passive sensitization of human airways increases the responses to $\mathrm{KCl}$ [5] and contractile neuropeptides [7]; it augments smooth muscle shortening velocity and capacity, as well as myogenic responses $[8,9]$, and decreases the relaxant responses to bronchodilating neuropeptides [7].

LTs are believed to be the main mediators of IgEdependent contractile responses to allergen in isolated human airways. By analogy to the induction of bronchial hyperresponsiveness to histamine, it was hypothesized that not only is the release of LTs increased in sensitized airways [1] but that, in addition, the responsiveness of the airway smooth muscle to LTs is enhanced. Therefore, the aim of this study was to investigate the effect of passive sensitization on $\mathrm{LTC}_{4}$-induced contractions in human airway smooth muscle.

\section{Methods}

\section{Tissue preparations}

Macroscopically normal airways were obtained from nine patients undergoing surgery for lung cancer (table 1). None were chronically treated with theophylline, $\beta$-adrenoceptor 
Table 1. - Details of tissue donors

\begin{tabular}{|c|c|c|c|c|c|c|c|c|}
\hline $\begin{array}{l}\text { Patient } \\
\text { No. }\end{array}$ & Sex & $\begin{array}{l}\text { Age } \\
\text { yrs }\end{array}$ & Smoking status ${ }^{+}$ & Pack-yrs & $\begin{array}{c}\mathrm{VC} \\
\mathrm{L}\end{array}$ & $\begin{array}{l}\text { FEV1 } \\
\% \text { pred }\end{array}$ & Histology & $\begin{array}{l}\text { Total IgE } \\
\mathrm{U} \cdot \mathrm{mL}^{-1}\end{array}$ \\
\hline 1 & $\mathrm{~F}$ & 73 & Ex & 30 & 2.07 & 93 & $\mathrm{AdCa}$ & 159 \\
\hline 2 & M & 51 & Ex & 65 & 3.45 & 70 & $\mathrm{SqCa}$ & 83 \\
\hline 3 & M & 66 & Yes & 25 & 3.69 & 99 & $\mathrm{SqCa}$ & $<10$ \\
\hline 4 & M & 38 & Yes & 12 & 4.5 & 94 & Sequester & 18 \\
\hline 5 & M & 61 & Ex & 45 & 2.01 & 55 & AdCa & 158 \\
\hline 6 & M & 52 & Ex & 15 & 5.45 & 113 & Met & 11 \\
\hline 7 & M & 61 & Yes & 40 & 4.34 & 82 & $\mathrm{AdCa}$ & 180 \\
\hline 8 & $\mathrm{M}$ & 48 & $\mathrm{Ex}$ & 75 & 4.53 & 104 & $\mathrm{SqCa}$ & 191 \\
\hline 9 & $\mathrm{M}$ & 76 & Yes & 83 & 4.42 & 82 & $\mathrm{SqCa}$ & 21 \\
\hline Mean & & 58 & & 43 & 3.83 & 88 & & 92 \\
\hline SEM & & 4 & & 9 & 0.39 & 6 & & 26 \\
\hline
\end{tabular}

+: Ex=stopped smoking 6 months prior to the study, Yes=current smoker until the week before surgery. VC: vital capacity; FEV1: forced expiratory volume in one second, \% of predicted [10]; IgE: immunoglobulin E; F: female; M: male; AdCa: adenocarcinoma; $\mathrm{SqCa}$ : squamous cell carcinoma; Met: metastases.

agonists, corticosteroids or anticholinergic drugs. All patients showed a negative history of atopy. Serum IgE levels of all tissue donors were measured shortly after surgery. Immediately after resection, peripheral airways (1-3 $\mathrm{mm}$ internal diameter) were dissected free of alveolar tissue and cut into rings (2-4 mm long).

\section{Passive sensitization}

Tissues were rotated overnight at room temperature in tubes containing modified Krebs buffer (composition in $\mathrm{mM}: \mathrm{NaCl} 118.4, \mathrm{KCl} 4.7, \mathrm{MgSO}_{4}$ 0.6, $\mathrm{CaCl}_{2}$ 1.3, $\mathrm{KH}_{2} \mathrm{PO}_{4} 1.2, \mathrm{NaHCO} 325.0$, glucose 11.1; $\left.\mathrm{pH} 7.4\right)$ in the absence or presence of sensitizing serum $(10 \% \mathrm{v} / \mathrm{v})$. The sensitizing serum was prepared from the whole blood of individuals who demonstrated high total $\operatorname{IgE}(>250$ $\mathrm{U} \cdot \mathrm{mL}^{-1}$ ) and specific IgE-antibodies (fluorescent allergosorbent test (FAST) class $\geq 3$ ) against allergen (Dermatophagoides farinae). Sera were not pooled but were stored frozen at $-20^{\circ} \mathrm{C}$ in $200-250 \mu \mathrm{L}$ aliquots until required. The following morning, rings were transferred to $10 \mathrm{~mL}$ organ baths (GlaxoWellcome Medicines Research, UK) containing oxygenated $\left(95 \% \mathrm{O}_{2}, 5 \% \mathrm{CO}_{2}\right)$ modified Krebs buffer $\left(\mathrm{pH} 7.4 ; 37^{\circ} \mathrm{C}\right)$.

\section{Tension measurements}

Tissues were equilibrated in modified Krebs buffer for $\geq 60 \mathrm{~min}$ at a resting tension of $\sim 400 \mathrm{mg}$ before a single dose $(1 \mu \mathrm{M})$ of the $\beta$-adrenoceptor agonist isoproterenol was applied to determine the amount of inherent tone. After full recovery of the tissues, histamine concentration/ effect curves $(10 \mathrm{nM}-300 \mu \mathrm{M})$ were performed. Contractile responses measured in milligrams were recorded. After washing and re-equilibration of the tissues for $\sim 60 \mathrm{~min}$, LTC $_{4}$ concentration/effect curves $(3 \mathrm{pM}-0.3 \mu \mathrm{M})$ were assessed. All concentration/effect curves were constructed in a cumulative manner, using incremental concentrations spaced at half $\log _{10}$ intervals. To ensure that negative responses to $\mathrm{LTC}_{4}$ were not the result of deterioration of contractile responses, tissues were exposed to a single concentration of spasmogen (carbachol $0.1 \mathrm{mM}$ ) at the end of the experiments. Finally, the wet weight of each tissue was determined at the end of the experiments.

\section{Measurements and analysis of results}

All responses were recorded as absolute changes in isometric tension $(\mathrm{mg})$. The potency of histamine and $\mathrm{LTC}_{4}$ was calculated from concentration/effect curves by nonlinear curve-fitting using the InPlot $\mathbb{R}$ ) program (Graph$\mathrm{Pad}^{\mathrm{TM}}$ Software, San Diego, CA, USA) for each individual tissue and expressed as the $-\log _{10}$ of the concentration causing a half-maximal effect (pEC50). All values are expressed as the mean \pm SEM of the indicated number of experiments with tissues derived from different individuals. Statistical analysis of the data was performed using the paired t-test. To study the relationship between the responses to histamine and $\mathrm{LTC}_{4}$, the linear correlation coefficients were computed. A p-value $<0.05$ was considered significant.

\section{Materials}

Isoproterenol, histamine and carbachol were obtained from the Sigma Chemical Company (Deisenhofen, Germany); $\mathrm{LTC}_{4}$ was purchased from the Cayman Chemical Company (Ann Arbor, MI, USA).

Isoproterenol, histamine and carbachol were dissolved in distilled water; LTC $_{4}$ was dissolved in Hanks' balanced salts solution containing $1 \%(\mathrm{w} / \mathrm{v})$ bovine serum albumin.

\section{Results}

\section{Baseline characteristics of the bronchial rings}

There was no significant difference between passively sensitized and nonsensitized tissues in wet weight ( $8.63 \pm 0.77$ versus $9.66 \pm 0.83 \mathrm{mg})$, resting tension ( $370 \pm 29$ versus $428 \pm 21 \mathrm{mg}$ ) or inherent tone (the magnitude of relaxation after a single dose of isoproterenol, $217 \pm 20$ versus $220 \pm 33 \mathrm{mg}$ ).

\section{Effect of passive sensitization on histamine responses}

Histamine caused concentration-dependent contractions in both sensitized and nonsensitized preparations (fig. 1 ). The magnitude of the maximal contractions was 


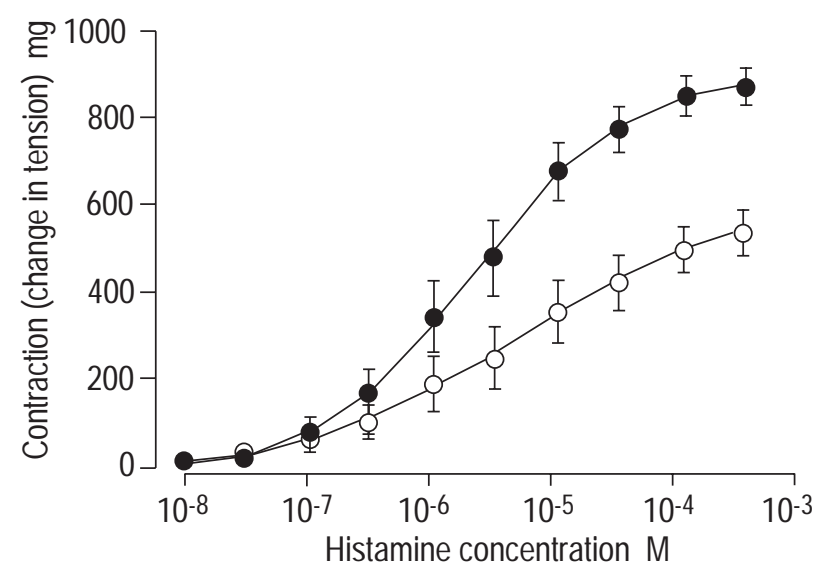

Fig. 1. - Contractile concentration/effect curves to histamine in nonsensitized $(\bigcirc)$ and passively sensitized $(\bigcirc)$ airway tissue preparations. Data are the mean \pm SEM of nine experiments.

significantly greater in serum-sensitized $(877 \pm 47 \mathrm{mg}, 110$ $\pm 14 \mathrm{mg} \cdot \mathrm{mg}$ wet weight $\left.{ }^{-1}\right)$ than in nonsensitized tissues $\left(543 \pm 51 \mathrm{mg}, 61 \pm 9 \mathrm{mg} \cdot \mathrm{mg}\right.$ wet weight ${ }^{-1} ; \mathrm{p}<0.005$, for each) from the same individual. In addition, the potency of histamine was significantly increased in sensitized (pEC50, 5.64 \pm 0.18 ) compared to nonsensitized tissues $(5.20 \pm 0.27 ; \mathrm{p}=0.02)$.

Effect of passive sensitization on leukotriene C4 responses

$\mathrm{LTC}_{4}$ caused concentration-dependent contractions in both serum-sensitized and nonsensitized preparations (fig. $2)$. The magnitude of maximal contractions was significantly greater in sensitized tissues $(811 \pm 57 \mathrm{mg}, 102 \pm 13$ $\mathrm{mg} \cdot \mathrm{mg}$ wet weight ${ }^{-1}$ ) compared to nonsensitized tissues (361 $\pm 86 \mathrm{mg}, 41 \pm 12 \mathrm{mg} \cdot \mathrm{mg}$ wet weight ${ }^{-1} ; \mathrm{p}<0.001$, for each) from the same individual. The potency of $\mathrm{LTC}_{4}$ was also significantly increased in serum-sensitized tissues (pEC50, 9.37 \pm 0.20 ) compared to nonsensitized tissues $(8.66 \pm 0.26 ; \mathrm{p}=0.004)$.

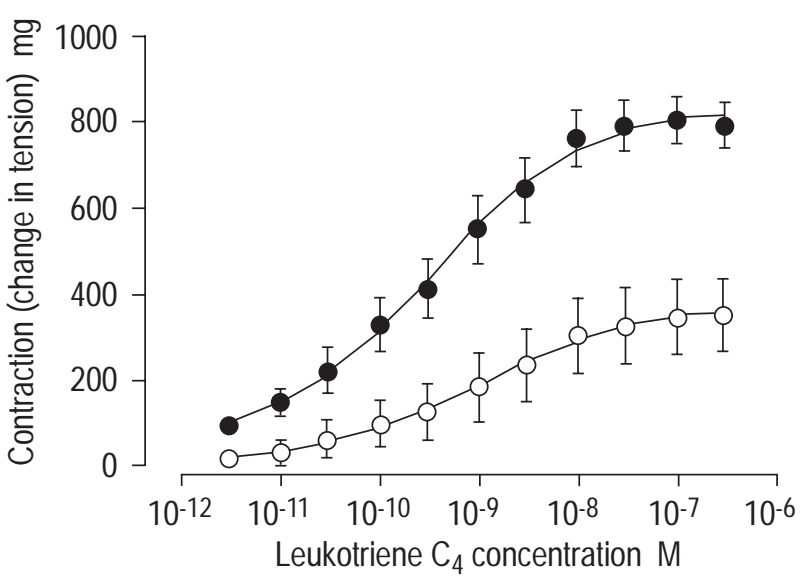

Fig. 2. - Contractile concentration/effect curves to leukotriene (LT)C 4 in nonsensitized $(\mathrm{O})$ and passively sensitized (O) airway tissue preparations. Data are the mean \pm SEM of nine experiments.
Relationship between leukotriene $C_{4}$ and histamine responses

There was a significant correlation between the responses to $\mathrm{LTC}_{4}$ and histamine in passively sensitized and nonsensitized tissues, both for maximal contractions $(\mathrm{r}=$ $0.70, p=0.0007$; fig. $3 a$ ) and the potency expressed as pEC50 ( $r=0.52, p=0.01$; fig. $3 b)$.

\section{Discussion}

This study demonstrates that passive sensitization of human airways causes increased responsiveness to $\mathrm{LTC}_{4}$ in vitro. Furthermore, airway responsiveness to $\mathrm{LTC}_{4}$ and histamine were related to each other. These data suggest that allergen responsiveness in passively sensitized airways is not only associated with an increased release of these mediators from inflammatory cells, but also with an increased reactivity of the airway smooth muscle to both of these mediators.

The present data are in agreement with previous reports that passive sensitization, in addition to the induction of allergen responsiveness [4], induces nonspecific hyperresponsiveness to histamine in isolated human airways.

a)

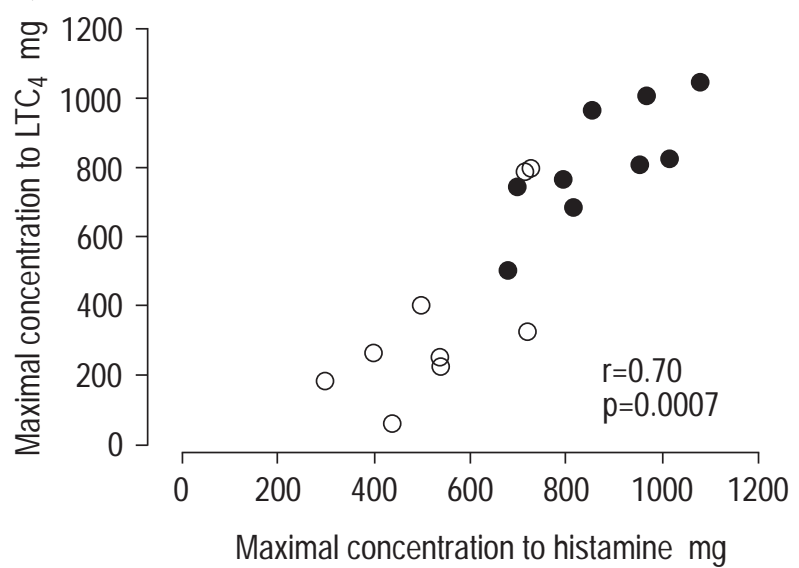

b)

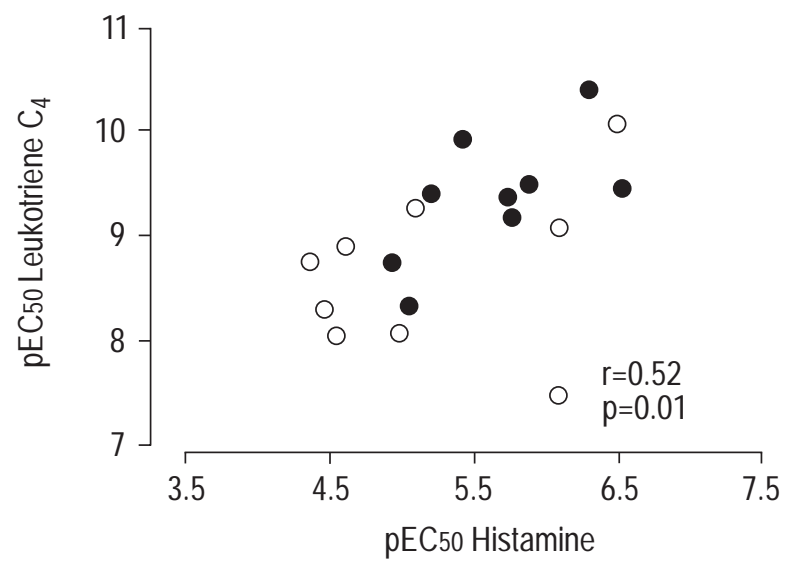

Fig. 3. - Relationship between a) maximal contractions to histamine and leukotriene (LT) $C_{4}$ and b) potencies expressed as the $-\log _{10}$ of the concentration causing a half-maximal effect (pEC50) in passively sensitized $(\bigcirc)$ and nonsensitized airway tissues $(\bigcirc)$. 
This is reflected by an increase in the magnitude of maximal contraction $[5,6]$ and a leftward shift in the concentration/effect curves, i.e. an increase in potency [4]. However, the contribution of histamine to allergen responses in vitro appears to be of minor importance, whereas LTs are believed to be the single most important class of mediators [2]. The induction of allergen responses by passive sensitization depends primarily on the presence of specific IgE antibodies in the sensitizing serum $[4,11]$ and is most likely effected through the liberation of mediators from mast cells. Although LTs are major contributors to allergen responses in vitro and in vivo, it is surprising that the effect of passive sensitization on airway responsiveness to LTs has not been investigated to date, in contrast to the responsiveness to histamine and other nonspecific stimuli [5-9, 12].

The novel finding of the present study is that passive sensitization of human airways increased the responsiveness to $\mathrm{LTC}_{4}$ compared to nonsensitized control tissues. The shift in potency as well as in maximal contractions caused by passive sensitization was of a similar magnitude to the shift observed in response to histamine. It is noteworthy that in these experiments, the shift in the potencies for either stimulus caused by passive sensitization was approximately a half $\log$ concentration, the potency ratio between $\mathrm{LTC}_{4}$ and histamine was $\sim 1000: 1$, both findings being in accordance with earlier studies in isolated human bronchi $[4,13,14]$.

Furthermore, these data present a close analogy to the in vivo finding [15] that there is a significant correlation between the airway reactivity to $\mathrm{LTE}_{4}$ and histamine in patients with bronchial asthma as well as normal subjects. The present results demonstrate a comparable relationship in passively sensitized and nonsensitized bronchi in vitro. This analogy underlines the notion that passive sensitization is a useful in vitro model for nonspecific and specific airway hyperresponsiveness and closely mimics clinical findings.

It is noteworthy that, in contrast to allergen responsiveness, the induction of nonspecific bronchial responsiveness is independent of serum $\operatorname{IgE}$ but dependent upon a still unknown serum factor that appears to be IgE-related [16]. Since hyperresponsiveness in sensitized human airways has been demonstrated with many different nonspecific stimuli [5-9], it is conceivable that the nonspecific hyperresponsiveness reflects alterations of the airway smooth muscle itself [17]. This may include changes in contractile proteins or their activating enzymes such as myosin light chain kinase [18-20], ion channels, in particular calcium channels [5], or changes in cell membrane potentials [21].

Airway preparations contain different cell types such as smooth muscle cartilage, epithelial and inflammatory cells. Although it is likely that an alteration of airway smooth muscle plays an important role in the induction of hyperresponsiveness, the heterogeneity of the preparations poses a limitation to the conclusions on the underlying mechanisms that can be derived from the present experiments. For example, it has been shown that the activation and/or distribution of mast cells is altered in sensitized airways [22, 23]. Further analysis of sensitization-induced changes within the tissue will have to be evaluated separately for different cell types in order to link those changes to underlying mechanisms of the induction of airway hyperresponsiveness.

In summary, this study demonstrates that passive sensitization of isolated human airways induces hyperresponsiveness to $\mathrm{LTC}_{4}$, in addition to histamine. Therefore, it is concluded that the induction of allergen responses in passively sensitized airways may not only be related to an increased release of mediators such as $\mathrm{LTC}_{4}$ and histamine, but also to an enhanced responsiveness of the airway smooth muscle to these mediators.

It is known that in patients with extrinsic asthma, allergen challenge causes an increased release of leukotrienes, as indicated by elevated levels in bronchoalveolar lavage fluid or urine [1]. The current data suggest that the effects of even small increases in leukotriene levels might be underestimated only if these changes are taken into account and not the concomitant increase in smooth muscle responsiveness to leukotrienes.

\footnotetext{
Acknowledgements. The authors would like to thank the surgical staff of Krankenhaus Grosshansdorf for their cooperation and the members of the Clinical Laboratory for performing the total and specific $\operatorname{IgE}$ analysis.
}

\section{References}

1. Roquet A, Dahlen B, Kumlin $\mathrm{M}$, et al. Combined antagonism of leukotrienes and histamine produces predominant inhibition of allergen-induced early and late phase airway obstruction in asthmatics. Am J Respir Crit Care Med 1997; 155: 1856-1863.

2. Björck T, Dahlén S-E. Leukotrienes and histamine mediate IgE-dependent contractions of human bronchi: pharmacological evidence obtained with tissues from asthmatic and nonasthmatic subjects. Pulm Pharmacol 1993; 6: 87-96.

3. Dunlop LS, Smith AP. Reduction of antigen-induced contraction of sensitized human bronchus in vitro by indomethacin. Br J Pharmacol 1975; 54: 495-497.

4. Watson N, Bodtke K, Coleman RA, et al. Role of IgE in hyperresponsiveness induced by passive sensitization of human airways. Am J Respir Crit Care Med 1997; 155: 839-844.

5. Black JL, Marthan R, Armour CL, Johnson PRA. Sensitization alters contractile responses and calcium influx in human airway smooth muscle. $J$ Allergy Clin Immunol 1989; 84: 440-447.

6. Marthan R, Crevel H, Guenard H, Savineau JP. Responsiveness to histamine in human sensitized airway smooth muscle. Respir Physiol 1992; 90: 239-250.

7. Ben-Jebria A, Marthan R, Rossetti M, Savineau J-P. Effect of passive sensitization on the mechanical activity of human isolated bronchial smooth muscle induced by substance P, neurokinin A and VIP. Br J Pharmacol 1993; 109: 131-136.

8. Mitchell RW, Rühlmann E, Magnussen H, Leff AR, Rabe KF. Passive sensitization of human bronchi augments smooth muscle shortening velocity and capacity. $\mathrm{Am} \mathrm{J}$ Physiol 1994; 267: 218-222.

9. Mitchell RW, Rabe KF, Magnussen H, Leff AR. Passive sensitization of human airways induces myogenic contractile responses in vitro. J Appl Physiol 1997; 83: 12761281. 
10. Quanjer PH, Tammeling GJ, Cotes JE, Pedersen OF, Peslin R, Yernault JC. Lung volumes and forced ventilatory flows. Report: working party standardization of lung function/tests, European Community for Steel and Coal. Official statement of the European Respiratory Society. Eur Respir J 1993; 6: Suppl. 16, 5-40.

11. Rabe KF, Watson N, Dent G, et al. Inhibition of human airway sensitization by a novel monoclonal anti-IgE antibody, 17-9. Am J Respir Crit Care Med 1998; 157: 1429-1435.

12. Roberts JA, Thomson NC. The effect of passive sensitisation of human bronchial smooth muscle on in vitro sensitivity to histamine. Pulm Pharmacol 1989; 2: 103-105.

13. Dahlén S-E, Hedqvist P, Hammarström S, Samuelsson B. Leukotrienes are potent constrictors of human bronchi. Nature 1980; 288: 484-486.

14. De Jongste J, Mons H, Van Strik R, Bonta I, Kerrebijn K. Human small airway smooth muscle responses in vitro; actions and interactions of methacholine, histamine and leukotriene $\mathrm{C}_{4}$. Eur J Pharmacol 1986; 125: 29-35.

15. O'Hickey SP, Arm JP, Rees PJ, Spur BW, Lee TH. The relative responsiveness to inhaled leukotriene $\mathrm{E}_{4}$, methacholine and histamine in normal and asthmatic subjects. Eur Respir J 1988; 1: 913-917.

16. Watson N, Rühlmann E, Magnussen H, Rabe KF. Histamine hypersensitivity induced by passive sensitization of human bronchus: effect of serum $\mathrm{IgE}$ depletion. Clin Exp Allergy 1998; 28: 679-685.
17. Solway J, Fredberg JJ. Perhaps airway smooth muscle dysfunction contributes to asthmatic bronchial hyperresponsiveness after all. Am J Respir Cell Mol Biol 1997; 17: 144-146.

18. Jiang H, Halayko AJ, Liu X, Stephens NL. Ragweed sensitization-induced increase of myosin light chain kinase content in canine airway smooth muscle. $\mathrm{Am} J$ Respir Cell Mol Biol 1992; 7: 567-573.

19. Ammit AJ, Armour CL, Black JL. Myosin light chain kinase content is increased in human sensitized airway smooth muscle. Am J Respir Crit Care Med 1997; 155: A370.

20. Mitchell RW, Halayko AJ, Rabe KF, Leff AR. Relative content of smooth muscle $\alpha$-actin, myosin heavy chain, and light chain kinase (MLCK) of human airways is unaffected by passive sensitization. Am J Respir Crit Care Med 1998; 157: A746.

21. Souhrada M, Souhrada JF. Immunologically induced alterations of airway smooth muscle cell membrane. Science 1984; 225: 723-725.

22. Ammit AJ, Bekir SS, Johnson PR, Hughes JM, Armour CL, Black JL. Mast cell numbers are increased in the smooth muscle of human sensitized isolated bronchi. Am J Respir Crit Care Med 1997; 155: 1123-1129.

23. Berger P, Walls AF, Marthan R, Tunon de Lara JM. Immunoglobulin E-induced passive sensitization of human airways: an immunohistochemical study. $A m ~ J$ Respir Crit Care Med 1998; 157: 610-616. 